\title{
Environmental Accounting Challenges of Selected Manufacturing Enterprises in Bangladesh
}

\author{
Md. Musharof Hossain \\ Department of Business Administration, International Islamic University Chittagong, Chittagong, Bangladesh \\ Email: musharof_cu@yahoo.com
}

How to cite this paper: Hossain, Md.M. (2019) Environmental Accounting Challenges of Selected Manufacturing Enterprises in Bangladesh. Open Journal of Business and Management, 7, 709-727. https://doi.org/10.4236/ojbm.2019.72048

Received: January 28, 2019

Accepted: April 6, 2019

Published: April 9, 2019

Copyright (อ 2019 by author(s) and Scientific Research Publishing Inc. This work is licensed under the Creative Commons Attribution International License (CC BY 4.0).

http://creativecommons.org/licenses/by/4.0/ (c) (i) Open Access

\begin{abstract}
Considering the importance as well as potential problems of environment issues, it needs more analysis of relevant factors for future course of actions. Environmental Accounting is called green accounting. This paper made on Challenges of Environmental Accounting Practices in Bangladesh on most polluted 16 selected enterprises in Chittagong during the period 2018. The main objective of the study is to specify the environmental accounting challenges in selected manufacturing enterprises in Bangladesh. The study is based on primary data. Primary data were collected by questionnaire and expert opinion. Questionnaires were prepared based on study objectives. Collected data were processed manually and with help of the Computer software. The study highlights some critical challenges to implement environmental accounting in manufacturing enterprises in Bangladesh. The perception of respondents about the Challenges are: cost involvement, lack of skilled manpower, lack of set rules about environmental accounting, inadequate environmental accounting standard, low adoption of environmental accounting, no specific principles of environmental accounting etc. The average mean score of challenges is 2.47 in the scale of 3 . The study also tries to forward some recommendations to overcome the challenges. It is to be recognized that the accountants have a key role in environmental accounting and reporting.
\end{abstract}

\section{Keywords}

Environment, Environmental Accounting, Challenges, Disclosure

\section{Prelude}

As environmental accounting has become more important nowadays, investors 
and consumers are demanding more and more information on a company's environmental and social performance. Development of environmental accounting is comparatively slow in Bangladesh while comparing with other countries. In the case of corporate sectors, accounting for the financial aspects of an organization's performance is a statutory requirement but accounting for environmental aspects is voluntary activity in Bangladesh. Some of the studies conducted on EA reveal a number of flaws in EA in Bangladesh. After independence, a good number of industrial units were established in different areas of Bangladesh without considering environmental issues. Further it is revealed from the study of Rahman [1] that many people are being affected due to industrial pollution. Further, Reazuddin [2] states that large, medium and small scale manufacturing companies have created huge environmental problems in Bangladesh. According to the United Nations, Economic and Social Commission Report [3] unsustainable industrialization and non-compliance with environmental regulations are mainly responsible for the environmental degradation in developing countries.

EA refers to the incorporation of environmental costs and information in to a variety of accounting practice. At macroeconomics level, EA is used to account for cost associated with a region's stocks and flows of natural resources. EA accounts for the flow and renewable and non-renewable resources through a region (natural resources accounting) or the flow of goods and services through an economy (national income accounting) in such a level. In case of financial accounting, an enterprise records and reports its economic activities to an external audience where there is requirement for disclosure of environmental liabilities and certain environmental costs. In case of management accounting, EA is the way to gather and report in a predesigned way the material use and environmental costs there of in their operations. In fact, environmental accounts provide data which highlight both the cost and action as to environmental protection taken by enterprises, the contribution of natural resources to economic well-beings and the cost imposed by pollution or resources degradation of the environment which is a precious gift of nature. The factory workers and inhabitants of the immediate surroundings of the industrial concerns of the third world countries often face exposure to harmful chemicals which are more prone to health hazards caused by industrials pollutions Hammer. Hence a study on the Challenges of Environmental Accounting Practices is highly warranted issue in Bangladesh. But the crux of the problem is that in most of the sectors of Bangladesh, the use of environmental accounting practices is not mandatory. As a developing country, the potential of Environmental data generation and analysis is very significant because different types of pollution are being caused by different corporate sectors such as air pollution, water pollution, sound pollution, deforestation etc. The measures taken to overcome or minimized such pollution along with cost and the like need evaluation for assessing status of EA leading to furtherment of the situation. The study has investigated the status and use of Environmental Accounting in sample enterprises and has also evaluated the 
perception of respondents thereof in the sample which are highly polluted manufacturing companies in Bangladesh. The article is organized in different parts. Firstly, introductory that researcher has discussed significant of the environmental accounting challenges. Secondly, the Literature review has given the research question. Thirdly, Research methodology based on primary data by questionnaire. The researcher has tried to identify some challenges of EA such as cost involvement, lack of skilled manpower etc. Finally, the researcher finds out related findings and gives some suggestion of environmental accounting challenges.

\section{Literature Review}

This part with literature review published at home and abroad related to challenges of environmental accounting. It will make an attempt to high light the findings of these literature in relevant aspects and will identify research gap that exist in this field. Review of available literature, that could be made available, now follows: Boyed [4], in a study stressed that improved Environmental Accounting is not seen by corporate managers and environmental advocate a like as a necessary complement to improved environmental decision making within the private sector. Environmental Accounting may not necessarily lead to improvement in the quality of life for everyone. The results indicate the Environmental Accounting in the Fiji Sugar corporations focuses on legitimizing the environmentally sensitive nature of the company's operations rather than being an attempt to extend stewardship to the stakeholders that may be affected by the company's operations [5]. It is noted that, Hecht [6], in a paper stated that the challenges of national income accounting and Environmental Accounting.

However, Environmental awareness, current disclosure practices and problems associated with Environmental Accounting and reporting of twenty large and medium sized companies from industrial sector in Bahrain [7]. Notably, Chauhan [8] a standard system of environmental accounting is not yet evolving in India [9] the authors are of the view that Environmental Accounting can face challenges of large \& small, industrial, manufacturing and service sectors. Companies also face some methods problems such as water costs, activity based management, total quality management and process reengineering.

Although, Ramesh [10] the author is found in this paper to deal with insufficient elements of Environmental cost. Electricity, fuel, gas, lubricant oil, conventional and non-conventional energy cost and also considers cost and benefit. Dijk et al. [11] the authors in a paper pointed out that Australia's law and concentrated population density and the short history since European settlement contribute to the lack of environmental data. Moreover, Tsui has made a study of financial regulation and reporting. In adequate publicity of Environmental management accounting, insufficient agreement between accountants and environmental management departments were major barriers of EMA adoption.

Similarly, Shill and Iqbal [12] in their study states that Environmental Ac- 
counting emerges as a tool to prove this commitment. The authors also pointed out that the corporate environmental reporting and disclosure is still at an initial stage in Bangladesh and it needs further development. It is noted that, very few number of companies are showing environmental related data in annual report [13]. The author in fact made a preliminary overview of environmental accounting. Islam \& Das [14] in the context of EA the authors evaluated Green banking in Bangladesh. They asserted that Green banking is a new way of conducting the banking business through considering the hygienic environmental issue as well as corporate social responsibility. Ullah et al. [15] in another study the authors found that $31 \%$ of the sample companies addressed on environmental issues in their annual reports. Textile industries disclosed very poor information regarding environmental aspects where variation of disclosure among the industries is considerably high.

On the other hand, Ahsanuddin \& Saifuddin [16] in a study finds that on an average the selected companies disclosed $50.34 \%$ requirements while the standard deviations is very high (about 17.60\%) indicating companies are inconsistent in disclosing requirement. The authors opine that companies in Bangladesh are disclosing very inadequate narrative reporting information in their annual reports which are published source of information to stakeholders. Hossain [17] in a study about disclosure of Environmental information found that only 9.97 Pharmaceuticals and Chemicals Companies disclose more information in the annual report. Only two companies disclosed maximum 18 environmental factors in their annual report out of 74 factors. EA has been used increasingly day by day in the developed and developing countries and now-a-days, a good number of companies are putting their concern regarding EA and they are disclosing different environmental information in their annual reports. Though start is slow yet it seems that it will expand greatly in near future. Based on the above literature review we find that most of the studies were made on the disclosure practices of environmental information in the annual reports. There is a very scanty of research about the future Challenges in the environmental accounting practices in developing economy like Bangladesh.

\section{Objectives of the Study}

The main objective of the study is to specify challenges of environmental accounting in selected manufacturing enterprises in Bangladesh. The specific objectives are as follows:

1) To identify the challenges of environmental accounting practices in manufacturing enterprises

2) To provide policy recommendations for environmental accounting challenges in manufacturing enterprises of Bangladesh.

\section{Research Methodology}

The study is based on primary data. For the purpose of the study, an attempt was 
made to select purposive samples from most polluted eight manufacturing industries taking two from each i.e. 16 enterprises in Chittagong. The primary data were collected by questionnaire. The primary data was used for the purpose of the study.

Mainly, the formal interview has been conducted to gather primary data and opinions of respondents as to perceptions relevant to different aspects of EA. Notably, the author visited each sample enterprises more than twice for data collection and observation. The questionnaire had two facets viz., the open-ended question relevant to general information, and seven-point Likert bi-polar scale relevant to perceptions of the respondents towards various aspects of EA and EMI shown.

Five respondents were selected from each sample enterprise comprising top-level managers, accountants and concerned high-level officers who are involved in decision making. Thus primarily 80 respondents $(16 \times 5)$ comprised the total respondents. Respondents were supposed to be well informed about the companies present status of environment-related activities as well as future policy. Here it is to be mentioned that the Accountant was a common respondent of each sample enterprises. However, not all 80 respondents did respond adequately. As such in the final evaluation, actual respondents came to 61 (Table 1).

The data collected were tabulated both manually and by use of computer as per need. Different statistical tools such as frequency distribution, mean, and standard deviation were used to analyse the data. Data was coded and analyses by SPSS. Summary of the information in relevant case has been shown in tables where necessary through ranking.

\section{Scope of the Study}

Environmental Accounting is a new branch as well as a concept of accounting. In the present day context, everybody's concerns over environment has created a pressure on management to ensure environmental disclosure in their annual report, But most of organization reportedly is not concerned about environmental

Table 1. Shows the number of respondents with percentages.

\begin{tabular}{ccc}
\hline Sectors & Total number & $\%$ to total \\
\hline Pharmaceuticals \& chemicals & 9 & $14.75 \%$ \\
Textiles \& Clothing & 8 & $13.11 \%$ \\
Papers \& Printing & 7 & $11.48 \%$ \\
Leather \& Footwear & 8 & $13.11 \%$ \\
Steel Industry & 8 & $13.11 \%$ \\
Foods Allied & 7 & $11.48 \%$ \\
Energy & 8 & $13.11 \%$ \\
Cement & 6 & $9.84 \%$ \\
& 61 & $100 \%$
\end{tabular}


accounting practice. Many studies have been undertaken to explore the environmental accounting comprehensively from recording to reporting and disclosure in Bangladesh. A few studies have been conducted in Bangladesh, specifically on this issue of Challenges of EA. For these reasons, the research question of this study centre records to challenges of environmental accounting practices in Bangladesh. All these aspects of EA in 16 (sixteen) sample enterprises were included in the scope of the study. Samples and their selection have been described in methodology part of this study.

\section{Challenges of Environmental Accounting Practices of Manufacturing Enterprises in Bangladesh}

\subsection{General Problems}

Environmental Accounting needs to be managed properly and adequately. This necessity has given rise to Environmental Management Accounting. Environmental management accounting (EMA) is a part of environmental accounting which is the "accounting systems and techniques that provide decision-makers and management with financial and non-financial information about the firm or organization and its environment." [18] In this case, further, EMA is not likely to be successful if its promotion is inadequate. It is find out from Japanese companies, EMA information was incomplete and eco-efficiency information was underutilized due to insufficient public promotion [19].

EMA requires collaboration and actions of different functions, such as financial management and environmental management. But no logical relationship has yet been established between them. Setthasakko [20] found that accountants in Thailand did not have sufficient environmental knowledge and experience. Environmental issues are restricted to the existing accounting practices. $\mathrm{He}$ pointed out that Accountants in Thailand did not practice in creating EMA.

It is to be mentioned here that the application of IFAC/ UNDSD, EMA guidelines was not mandatory and companies use own definitions of environmental costs. Companies had their own definitions of environmental costs which made firms found collecting, identifying and evaluating environmental cost data difficult. Setthasakko [20]. Finally, managers were unwilling to adopt EMA as they were not willing to be held responsible for significant environmental costs. Gale [21] reported that after looking at the "true environmental costs", the managers of a paper mill in Canada who participated in the research project questioned the validity of EMA methodology and the managers decided not use EMA.

\subsection{General Challenges of EMA}

The above brief discussion indicates that the general problem of EA and EMA is less definition of Environmental cost, lack of willingness of managers to adopt EMA, lack of co-ordination among functional areas, lack of legal framework, inadequacy of guidelines and compulsion to adopt guidelines, etc. It is recognized that "the majority of management and cost accounting systems that are in 
placed within organization pay little or no attention to attributing any form of environmental cost to an organization's operations and as a result, many environmentally incurred costs are accumulated in overhead accounts such as energy and water costs, waste treatment costs, stationery costs, insurance from holding hazardous substances, or regulatory costs associated with particular emissions or release" [21]. The environmental cost is considered overhead accounts. United Nation Division for Sustainable Development; in fact the scenario is a like in Bangladesh.

Research on environmental costs revealed that environmental costs are generally higher than considered because costs are hidden in other accounts [22]. The total environmental costs were found to be at least twice as high according to EMA methodology as compared to conventional accounting.

"According to IFAC [23], the following challenges exist in most organizations management accounting systems:

1) Inadequate links between accounting and other departments;

2) Unintentional hiding of environmental-related costs information in overhead accounts;

3) Inadequate tracking of information on material use, flows, and costs;

4) Lack of some environmental-related information in the accounting records; and

5) Investment decisions made on the basis of incomplete environmental-related information.

The largest part of environmental cost lies in the purchase value of non-product output [24]. Wrongly allocating costs in particular costing categories can also result in "hidden" costs in the costs in the accounting system [22]."

\subsection{Perceptions of Respondents as to Challenges of Environmental Accounting: Bangladesh Context}

1) Environment issue is a burning issue in the present day context due to its damage caused by natural and human activities. Its safeguard and prevention is thus a serious concern to all-society and business. Against this backdrop, Environmental accounting and Environmental Management Accounting have become a research topic globally as well in Bangladesh. This is gaining recognition too. In such a context the present research was undertaken where in study of perceptions of respondent to EA and EMA was also undertaken as an important part of this study.

Study of perceptions of the respondents of sample enterprises Challenges. Here 13 statements were given to respondents to express their perceptions relevant to manpower skill, rules and regulations, information recording, organization and management etc. The responses were taken on Likerts 7 point bi-polar scale and evaluated thereof. In this context it is worthwhile to mention that the following factors are responsible for environmental pollution by manufacturing enterprises in Bangladesh: "Water abstraction, greenhouse gases, acid rain and smog, nuclear waste, dust and particles, coal, nutrients and organic pollutants, 
others." Against this backdrop, now an attempt is made below to evaluate the perceptions of the sample respondents as to problems of EA in Bangladesh relevant to above mentioned variables factors and other relevant matters, almost $97 \%$ respondent's shows positive opinion on this statement.

2) Perceptions of Respondents as to Challenges of environmental accounting

Various types of Challenges may come in the way to introduce and implement Environmental Accounting. It is urgently necessary to find out challenges beforehand so as to minimize the same or overcome the same so that it can be applied properly and help achieve efficiency. To this end efforts were made to know the perceptions of respondents as to Challenges they face or expect to face and the magnitude of such challenges. Following para deals with the same.

\section{i) Cost involvement}

Environmental Accounting and reporting will require extra manpower and cost. Many enterprises, unless otherwise compelled, may not be willing to incur such costs. Thus incurring additional cost may be considered as problems in introducing EA. To what extent such cost factor is considered as Challenges was thus a matter of investigation. To this end the average score of respondents worked out at 2.47 in the scale of 3 . This score lies between highest problem score 3 and moderate problem 2 . Thus respondents found to consider it as a significant problem. Table below depicts the status of the responses more explicitly. The 59\% (36) respondents reveal high degree of positiveness, $32.8 \%$ (20) reveal moderately high, $6.6 \%$ (4) respondents somewhat high, one respondent $1.6 \%$ high degree of negativeness on cost involvement is an important issue to the enterprise in adopting environmental accounting.

\section{ii) Lack of skilled manpower}

People's educated, skilled workers are vital for the efficient and effective implementation of EA. In such a context the respondents were requested to express their opinion as to this challenge. It is seen that respondents perceive the existence of skilled human resources must as the average score of the respondent's perceptions worked out positive at 2.54 in the scale of 3 . The $67.2 \%$ (41) respondents show the high degree of positiveness, $23 \%$ (14) respondents moderately high, $8.2 \%$ (5) respondents somewhat high and $1.6 \%$ (1) respondent's very low degree of negativeness on lack of skilled workforce is an obstacle for the environment.

\section{iii) Lack of consciousness about environmental accounting}

Manufacturing organisation does not record correctly on the different account of environmental accounting. Many institutions intentionally avoid separate environmental accounts. The respondents requested to give an opinion on this statement. The average mean score pointed out 2.54 in the scale of 3 . This score lies between high problem score 3 and moderate problem score 2 . The respondent thinks it is a significant problem. The $68.9 \%$ (42) respondents express high degree of positiveness, $19.7 \%$ express moderately high, $8.2 \%$ (5) respondents express somewhat high, and 3.35\% (2) respondents express no reply, on lack of consciousness in the manufacturing enterprises accounts for non-adoption of environmental accounting. 


\section{iv) Lack of set rules about environmental accounting}

Rules and regulations develop every organisation for smoothly run and overcome some problems. Proper set rules and regulation efficiently help implement environment accounting. The respondents were requested to the opinion on the lack of set rules about environmental accounting adversely affect appropriate implementation. The average score computed 2.63 indicate the proper rules and regulation is very essential. The $67.2 \%$ (41) respondent's show high degree of positiveness, $3.3 \%$ (2) respondents somewhat high and 29.5\% (18) moderately high and none of the respondents give any negative opinion for lack of set rules about environmental accounting adversely affects proper implementations.

\section{v) Inadequate environmental accounting standard}

Accounting has some accepted accounting standard for operating accounting practice. But there is no well-accepted international accounting standard for environmental accounting. The respondents think that adequate environmental accounting standard is necessary for the manufacturing organisation. The average score pointed out 2.45 in the scale of 3 that lies between the high positive and moderately positive. The $60.7 \%$ (37) respondents reveal the high degree of positiveness, $26.2 \%$ (16) reasonably high, $11.5 \%$ (7) respondents somewhat high and 1 respondents reveals. Thus the absence of environmental accounting standard poses the problem for standard compensation and presentation.

\section{vi) Lack of co-ordination with different stakeholders}

There are many stakeholders exist in manufacturing organisation viz., internal and external. But unfortunately, lack of coordination with different stakeholders related to environmental issues affect proper implementation. The respondents were requested to the opinion on this statement. The average mean score pointed out 2.57 in the scale of 3 shows the high positive problems of manufacturing. The $70.5 \%$ (43) respondents show high degree of positiveness, $19.7 \%$ (12) respondents moderately high, $6.6 \%$ (4) indicates somewhat high, $3.3 \%$ (2) respondents no reply on lack of coordination with different stakeholders related to environmental issues affect proper implementation.

\section{vii) Inadequate economic policy or incentive system}

Manufacturing organisation always tries to overcome environmental accounting challenges. Manufacturing organisations need an adequate economic policy or incentive system that affects motivation. The respondents were requested to the opinion on this statement. The average score computed 2.44 in the scale. That lies between the high positive score 3 and moderate score 2 . The $59 \%$ (36) respondents reveal a high degree of positiveness, $26.2 \%$ (16) respondents moderately high, $14.8 \%$ (9) respondents somewhat high and none of the respondents any negative reveal on poor economic policy or incentive system adversely affects motivation.

\section{viii) Institutional constraints of Environmental accounting.}

The institutional constraints of Environmental accounting are very important concerned issue. In such a context, the respondents were requested to express 
their perception as to this challenge. It is seen that the respondents represent average score 2.57 in the scale of 3 . The $70.5 \%$ (43) respondents show high degree of positiveness, $19.7 \%$ (12) respondents show moderately high, 6.6 (4) shows somewhat high, 3.3\% (2) respondents show no reply, and none of the respondents express any negativeness, that means about $97 \%$ of the respondents inform of this statement on institutional constraints adversely affect environmental accounting adoption.

\section{ix) Low adoption of environmental accounting.}

Planning is a future course of action. The respondents were requested to express their perception of this statement. The statement is very significant challenges of environmental accounting. The average score computed 2.42. The respondents indicate the positive opinion on this statement. The $52.5 \%$ (32) respondents express the high degree of positiveness, 39.3\% (24) respondents express moderately high, 6.6\% (4) respondents express somewhat high, and 1.6\% (1) respondents express improper enforcement of planning, and environmental legislation gives rise to the low adoption of environmental accounting.

\section{$\mathbf{x}$ ) Insufficient information affects recording and presentation}

Accounting is an information system. But insufficient information affects recording and presentation. The accountant can't record appropriately because of inadequate data. The respondents have given the opinion about this statement. The average score pointed out as 2.45 in the scale of 3 . The $65.6 \%$ (40) respondents show high degree of positiveness, $23 \%$ (14) respondents show moderately high and $8.2 \%$ (5) respondents show somewhat high. i.e. $97 \%$ shows positive response on the statement on insufficient information about environmental issues affect recording and presentation.

\section{xi) Slack governmental management accounts}

Slack governmental management accounts are very significant challenges of environmental accounting. The respondents were requested to the opinion on this statement. The average score shows the 2.49 in the scale of 3 . The $67.2 \%$ (41) high degree of positiveness, $21.3 \%$ (13) respondents indicate moderately high, 6.6\% (4) respondents show somewhat high, 3.3\% (2) respondents show no reply and only $1.6 \%$ (1) respondents indicate very low degree of negativeness on inactive enterprise participation and slack governmental management accounts for low adoption of environmental accounting.

\section{xii) No specific principles of environmental accounting}

The financial accounting standard board has stated financial accounting concept no 5: recognition and measurement for specific accounting principles but not given any environmental accounting principles. The respondents were requested to express their opinion on positive of the statement. The respondents think that absence of Environmental Accounting principles is a problem exists in manufacturing organisation in Bangladesh. The average score shows the 2.44 in the scale of 3 . The $63.9 \%$ (39) respondents express high degree of positiveness, 23\% (14) respondents moderately high, $8.2 \%$ (5) respondents somewhat high, $3.3 \%$ (2) respondents no 
reply and only $1.6 \%$ respondents show very high degree of negativeness on there are no specific principles of environmental accounting in Bangladesh.

xiii) Lack of measure to the environmental issues numerically.

Only very few manufacturing organization shows numerical information. It affects adversely on environmental accounting practice. The respondents were requested to express their opinion on this statement. The average score shows the 2.26 that lies between high degree of positiveness 3 and moderately degree of positiveness 2 . The maximum 60.75 (37) respondents show high degree of positiveness, $24.6 \%$ respondents moderately high, $4.9 \%$ (3) respondents show somewhat high, and $1.6 \%$ (1) respondents show very low on challenging to measure the environment issues numerically which adversely affect proper environmental accounting practice (Table 2).

Table 2. Opinions of respondents as to environmental accounting challenges.

\begin{tabular}{|c|c|c|c|c|c|c|c|c|}
\hline Statements & 3 & 2 & 1 & 0 & -1 & -2 & -3 & Total \\
\hline i. Cost involvement (f) & 36 & 20 & 4 & 1 & & & & $\sum f=61$ \\
\hline$(\mathrm{fx})$ & 108 & 40 & 4 & 0 & & & & $\sum f x=151$ \\
\hline Percentage (\%) & $59 \%$ & $32.8 \%$ & $6.6 \%$ & $1.6 \%$ & & & & $\begin{array}{c}\bar{x}=2.47 \\
(100 \%)\end{array}$ \\
\hline ii. Lack of skill manpower (f) & 41 & 14 & 5 & & 1 & & & $\sum f=61$ \\
\hline$(\mathrm{fx})$ & 123 & 28 & 1 & & -1 & & & $\sum f x=155$ \\
\hline Percentage (\%) & $67.2 \%$ & $23 \%$ & $8.2 \%$ & & $1.6 \%$ & & & $\begin{array}{c}\bar{x}=2.54 \\
(100 \%)\end{array}$ \\
\hline iii. Lack of conscious about (f) & 42 & 12 & 5 & 2 & & & & $\sum f=61$ \\
\hline Environmental Accounting ( $\mathrm{fx})$ & 126 & 24 & 10 & 0 & & & & $\sum f x=155$ \\
\hline Percentage (\%) & $68.9 \%$ & $19.7 \%$ & $8.2 \%$ & $3.3 \%$ & & & & $\begin{array}{c}\bar{x}=2.54 \\
(100 \%)\end{array}$ \\
\hline iv. Lack of set rules about Environmental Accounting (f) & 41 & 18 & 2 & & & & & $\sum f=61$ \\
\hline$(\mathrm{fx})$ & 123 & 36 & 2 & & & & & $\sum f x=161$ \\
\hline Percentage (\%) & $67.2 \%$ & $29.5 \%$ & $3.3 \%$ & & & & & $\begin{array}{c}\bar{x}=2.63 \\
(100 \%)\end{array}$ \\
\hline v. Inadequate Environmental Accounting standard (f) & 37 & 16 & 7 & 1 & & & & \\
\hline$(\mathrm{fx})$ & 111 & 32 & 7 & 0 & & & & $\sum f=61$ \\
\hline Percentage (\%) & $60.7 \%$ & $26.2 \%$ & $11.5 \%$ & 1.6 & & & & $\begin{array}{c}\sum f x=150 \\
\bar{x}=2.45 \\
(100 \%)\end{array}$ \\
\hline vi. Lack of co-ordination with different stakeholders ( $f$ ) & 43 & 12 & 4 & 2 & & & & $\sum f=61$ \\
\hline$(\mathrm{fx})$ & 129 & 24 & 4 & 0 & & & & $\sum f x=157$ \\
\hline Percentage (\%) & $70.5 \%$ & $19.7 \%$ & $6.6 \%$ & $3.3 \%$ & & & & $\begin{array}{c}\bar{x}=2.57 \\
(100 \%)\end{array}$ \\
\hline vii. Inadequate economic policy or incentive system $\mathrm{f}$ ) & 36 & 16 & 9 & & & & & $\sum f=61$ \\
\hline$(\mathrm{fx})$ & 108 & 32 & 9 & & & & & $\sum f x=151$ \\
\hline Percentage (\%) & $59 \%$ & $26.2 \%$ & $14.8 \%$ & & & & & $\begin{array}{c}\bar{x}=2.47 \\
(100 \%)\end{array}$ \\
\hline viii. Institutional constraints of Environmental Accounting (f) & 43 & 12 & 4 & 2 & & & & $\sum f=61$ \\
\hline$(\mathrm{fx})$ & 129 & 24 & 4 & 0 & & & & $\sum f x=149$ \\
\hline Percentage (\%) & $70.5 \%$ & $19.7 \%$ & $6.6 \%$ & $3.3 \%$ & & & & $\begin{array}{c}\bar{x}=2.44 \\
(100 \%)\end{array}$ \\
\hline
\end{tabular}




\section{Continued}

\begin{tabular}{|c|c|c|c|c|c|c|c|c|}
\hline ix. Low adoption of Environmental Accounting ( $f$ ) & 32 & 24 & 4 & 1 & & & & $\sum f=61$ \\
\hline$(\mathrm{fx})$ & 96 & 48 & 4 & 0 & & & & $\sum f x=157$ \\
\hline Percentage (\%) & $52.5 \%$ & $39.3 \%$ & $6.6 \%$ & $1.6 \%$ & & & & $\begin{array}{c}\bar{x}=2.57 \\
(100 \%)\end{array}$ \\
\hline $\mathrm{x}$. Insufficient information affects recording and presentation. $\mathrm{f}$ ) & 40 & 14 & 5 & & 1 & 1 & & $\sum f=61$ \\
\hline$(\mathrm{fx})$ & 120 & 28 & 5 & & -1 & -2 & & $\sum f x=148$ \\
\hline Percentage (\%) & $65.6 \%$ & $23 \%$ & $8.2 \%$ & & $1.6 \%$ & $1.6 \%$ & & $\begin{array}{c}\bar{x}=2.42 \\
(100 \%)\end{array}$ \\
\hline xi. Slack governmental management accounts f) & 41 & 13 & 4 & 2 & 1 & & & $\sum f=61$ \\
\hline$(\mathrm{fx})$ & 123 & 26 & 4 & 0 & -1 & & & $\sum f x=150$ \\
\hline Percentage (\%) & $67.2 \%$ & $21.3 \%$ & $6.6 \%$ & $3.3 \%$ & $1.6 \%$ & & & $\begin{array}{c}\bar{x}=2.45 \\
(100 \%)\end{array}$ \\
\hline xii. No specific principles of Environmental Accounting f) & 39 & 14 & 5 & 2 & 1 & & & $\sum f=61$ \\
\hline$(\mathrm{fx})$ & 117 & 28 & 5 & 0 & -1 & & & $\sum f x=147$ \\
\hline Percentage (\%) & $63.9 \%$ & $23 \%$ & $8.2 \%$ & $3.3 \%$ & $1.6 \%$ & & & $\begin{array}{c}\bar{x}=2.40 \\
(100 \%)\end{array}$ \\
\hline xiii. Lack of measure to the environmental issues $\mathrm{f}$ ) & 37 & 15 & 3 & 3 & 1 & 1 & 1 & $\sum f=61$ \\
\hline numerically. $(\mathrm{fx})$ & 111 & 30 & 3 & 0 & -1 & -2 & -3 & $\sum f x=138$ \\
\hline Percentage (\%) & $60.7 \%$ & $24.6 \%$ & $4.9 \%$ & $4.9 \%$ & $1.6 \%$ & $1.6 \%$ & $1.6 \%$ & $\begin{array}{c}\bar{x}=2.26 \\
(100 \%)\end{array}$ \\
\hline Overall Total f) & 508 & 200 & 61 & 16 & 5 & 1 & 1 & $\sum f=793$ \\
\hline$(\mathrm{fx})$ & 1524 & 400 & 61 & 0 & -5 & -2 & -3 & $\sum f x=1973$ \\
\hline Percentage (\%) & $65 \%$ & $25 \%$ & $7.83 \%$ & $2 \%$ & $0.006 \%$ & $0.001 \%$ & $0.163 \%$ & $\begin{array}{c}\bar{x}=2.47 \\
\%=100 \%\end{array}$ \\
\hline
\end{tabular}

Source: Field study and Literature survey.

\subsection{Statistical Data Analysis Showing Perception of Respondents on Challenges of EA}

It is evident from the Table 3 regarding descriptive statistical data about Challenges of environmental accounting; respondents show their valuable opinion on the basis of questionnaire. The maximum mean score shows 2.6313 on statements (iv) lack of set rules about environmental accounting adversely affect proper implementation, Lack of co-ordination stakeholder related with environmental issues affect proper implementation (vi) and also Institutional constraints adversely affect environmental accounting adoption mean score 2.5738, Lack of skill manpower is an obstacle for environmental accounting(ii) and Lack of consciousness in the manufacturing enterprises accounts for non-adoption of environmental accounting (iii) the mean score is 2.5410 . The minimum mean score shows 2.2623 of difficult to measure the environmental issues numerically which adversely affect proper environmental accounting practice. On average mean score shows 2.6393 in the scale of 3 . Where standard deviation indicates acceptable range of observation from mean score.

Ranking of Factors Relevant to Challenges of Environmental Accounting Practice Selected in Manufacturing Enterprises as Per Perception of Respondents

Table 4 shows the respondents perception in terms of percentage on different challenge statements. Among all statements Lack of co-ordination with different 
Table 3. Descriptive statistical data about challenges of environmental accounting.

\begin{tabular}{|c|c|c|c|c|c|}
\hline Statements & $\mathrm{N}$ & Minimum & Maximum & Mean & Std. Deviation \\
\hline $\begin{array}{l}\text { i. Cost involvement is an important issue to the enterprise in adopting } \\
\text { environmental accounting. }\end{array}$ & 61 & -1.00 & 3.00 & 2.4754 & 0.76608 \\
\hline ii.Lack of skill manpower is an obstacle for environmental accounting. & 61 & -1.00 & 3.00 & 2.5410 & 0.78685 \\
\hline $\begin{array}{l}\text { iii. Lack of consciousness in the manufacturing enterprises accounts for } \\
\text { non-adoption of environmental accounting. }\end{array}$ & 61 & 0.00 & 3.00 & 2.5410 & 0.78685 \\
\hline $\begin{array}{l}\text { iv. Lack of set rules about environmental accounting adversely affects proper } \\
\text { implementation. }\end{array}$ & 61 & 1.00 & 3.00 & 2.6393 & 0.54872 \\
\hline $\begin{array}{l}\text { V.Absence of environmental accounting standard poses problem for standard } \\
\text { compensation and presentation. }\end{array}$ & 61 & 0.00 & 3.00 & 2.4590 & 0.76537 \\
\hline $\begin{array}{l}\text { vi. Lack of co-ordination among the stakeholder related with environmental } \\
\text { issues affect proper implementation. }\end{array}$ & 61 & 0.00 & 3.00 & 2.5738 & 0.76287 \\
\hline vii. Inadequate economic policy or incentive system adversely affects motivation. & 61 & 1.00 & 3.00 & 2.4426 & 0.74217 \\
\hline viii. Institutional constraints adversely affect environmental accounting adoption. & 61 & 0.00 & 3.00 & 2.5738 & 0.76287 \\
\hline $\begin{array}{l}\text { ix. Improper enforcement of planning and environmental legislation gives rise to } \\
\text { low adoption of environmental accounting. }\end{array}$ & 61 & 0.00 & 3.00 & 2.4262 & 0.69424 \\
\hline $\begin{array}{l}x \text {. Insufficient information about environmental issues affects recording and } \\
\text { presentation. }\end{array}$ & 61 & -2.00 & 3.00 & 2.4590 & 0.97594 \\
\hline $\begin{array}{l}\text { xi. Inactive enterprise participation and slack governmental management } \\
\text { accounts for low adoption of environmental accounting. }\end{array}$ & 61 & -1.00 & 3.00 & 2.4918 & 0.88737 \\
\hline xii. There are no specific principles of environmental accounting in Bangladesh. & 61 & -3.00 & 3.00 & 2.4098 & 1.05478 \\
\hline $\begin{array}{l}\text { xiii. Difficult to measure the environmental issues numerically which adversely } \\
\text { affect proper environmental accounting practice. }\end{array}$ & 61 & -3.00 & 3.00 & 2.2623 & 1.27674 \\
\hline Valid N (list wise) & 61 & & & & \\
\hline
\end{tabular}

(Source: Survey and analysis through SPSS).

Table 4. Ranking of factors relevant to challenges of environmental accounting practice.

\begin{tabular}{|c|c|c|}
\hline Rank & Statements & Percent \\
\hline 1 & Lack of co-ordination stakeholder related with environmental issues affect proper implementation & $70.5 \%$ \\
\hline 1 & Institutional constraints adversely affect environmental accounting adoption. & $70.5 \%$ \\
\hline 2 & Lack of consciousness in the manufacturing enterprises accounts for non-adoption of environmental accounting & $68.9 \%$ \\
\hline 3 & Lack of skill manpower is obstacle for environmental accounting. & $67.2 \%$ \\
\hline 3 & Lack of set rules about environmental accounting adversely affects proper implementation. & $67.2 \%$ \\
\hline 3 & $\begin{array}{l}\text { Inactive enterprise participation and slack governmental management accounts for low adoption of environmental } \\
\text { accounting. }\end{array}$ & $67.2 \%$ \\
\hline 4 & Insufficient information about environmental issues affects recording and presentation & $65.6 \%$ \\
\hline 5 & There are no specific principles of environmental accounting in Bangladesh. & $63.9 \%$ \\
\hline 6 & Absence of environmental accounting standard poses problem for standard compensation and presentation & $60.7 \%$ \\
\hline 6 & Difficult to measure the environmental issues numerically which adversely affect proper environmental accounting practice. & $60.7 \%$ \\
\hline 7 & Cost involvement is an important issue to the enterprise in adopting environmental accounting. & $59 \%$ \\
\hline 7 & Inadequate economic policy or incentive system adversely affects motivation & $59 \%$ \\
\hline 8 & Improper enforcement of planning and environmental legislation give rise to low adoption of environmental accounting & $52.5 \%$ \\
\hline
\end{tabular}

Source: Table 2. 
stakeholders related with environmental issues affect proper implementation (vi) and Institutional constraints adversely affect environmental accounting adoption(viii) statements have shown highest $70.5 \%$, Lack of consciousness in the manufacturing enterprises accounts for non-adoption of environmental accounting(iii), Lack of set rules about environmental accounting adversely affects proper implementation(iv), Inactive enterprise participation and slack governmental management accounts for low adoption of environmental accounting(xi) is $67.2 \%$, Insufficient information about environmental issues affects recording and presentation $(\mathrm{x})$ is $65.6 \%$, on the other hand the lowest percentage is $52.5 \%$ of improper enforcement of planning and environmental legislation give rise to low adoption of environmental accounting (ix).

\section{Summary of the Findings}

It is evident from, Most of the enterprises are facing many environmental accounting challenges such as: lack of co-ordination, lack of compulsive guidance, lack of skilled persons, extra cost involvement etc. these are adversely affecting implementation of E.A. Notably, improper enforcement of environmental legislation give rise to low adoption of which environmental accounting challenges is the lowest $52.5 \%$. However, most of the organization is not provide sufficient information of environmental issue. So far, Government initiatives are not still enough to build strong platform of environmental accounting for manufacturing industry. It is observed that, Input relevant to EA is not easily available because of extra cost need to be incurred. Cost-benefit yet to recognized and evaluated do not properly consider. Respondents properly opine that Environmental Accounting work dependent with others. It should be integrated with the financial accounting, which is not easy. Enterprises in Bangladesh yet to perceive it well that Environmental Accounting must be analyzed along with other aspects of accounting. Many enterprises reportedly suffer from lack of skilled persons. In fact the user of information contained in the Environmental Accounting needs adequate knowledge of the process of EA. The initiation and operation of E.A in Bangladesh suffers a lot. In Bangladesh E.A operation is inefficient as there are no generally accepted accounting standards, Regulations, Rules, etc., against which the performance of organizations can be compared and evaluated. Lack of promotion on the use of environmental accounting management, lack of collaboration between accountants and environmental management departments were major barriers of Environmental Accounting operation. Finally, a review of financial statements of sample enterprises is revealed that most of the manufacturing companies disclose only qualitative information except of monetary value.

\section{Implications of the Study}

The study reveals that the vast majority of the respondents consider introduction and implementation of Environmental Accounting and Environmental Man- 
agement Accounting is necessary. But the crux of the problem is that the application and use of EA is limited and at initial stage in the sample enterprises. Lack of initiative from enterprise management, lack of skilled process, extra cost involvement are serious handicaps in the way of introduction and use of E.A. Information generated, collected and proper framework to install and operate EA are not adequate and proper. The environmental factors, organizational capacity, provision for maintaining separate sets of accounts staff, information management structure and attitude of management are not favorable to requirements though necessity are well recognized. In such circumstances what is urgently required is the establishment of legal framework, government initiative and instructions urgently required. At the same time proper guidance from accounting professional bodies is also called for. Enterprise initiative than can be expected to follow. Management awareness is not sufficient, what is required is the understanding of its necessity and, drawing up enterprise rules relevant to EA and EMA. For the sake of stability, sustainability and development of industrial growth keeping environmental hazard at minimum, recording and reporting environmental related information is a must for an economy like Bangladesh which is striving hard to grow in sustainable perspective.

\section{Recommendations}

It is to be recognized that environmental accounting and reporting have a significant role by an accountants [5]. However, Manufacturing organizations need individual environmental accounting department for recording and reporting. So that, Government should be taken necessary steps of environmental accounting rules and regulations. International accounting standard should be maintained overcome the environmental accounting challenges. The accountants need keep records up to date.

\section{Conclusion}

Challenges of Environmental Accounting need to be managed appropriately and adequately. An attempt has been made to identify relevant problems of EA as well EMA in the context of Bangladesh situation. Perceptions of selected respondents from most polluted manufacturing enterprises have analyzed which demonstrate highly prospects in future. In the same way, some important challenges or future problems have been identified which may draw the attention of the future policy planning for appropriate action.

\section{Conflicts of Interest}

The author declares no conflicts of interest regarding the publication of this paper.

\section{References}

[1] Rahman, K.D. (1992) Industrial Pollution and Control for Sustainable Develop- 
ment. Training Manual on Environmental Management in Bangladesh, Department of Environment (DoE), 23-26.

[2] Reazuddin, M. (1994) Industry and Pollution Related Issues. Environment and Development in Bangladesh, 2, 240-263.

[3] UNESCO (1992) Guideline on Monitoring Methodologies for Air, Water and Hazardous Industrial Wastes. United Nations Economic and Social Commission for Asia and the Pacific Region, 1-33.

[4] Boyd, J.W. (1998) The Benefits of Improved Environmental Accounting: An Economic Framework to Identify Priorities. Resource for the Future, Discussion Paper 98-49, Washington DC. http://www.rff.org./Boyd.cfm

[5] Lodhia, S.K. (1999) Environmental Accounting in Fiji-An Extended Case Study of the Fiji Sugar Corporations. Journal of Pacific Studies-Banking, Finance and Accounting, 23, 283-309.

[6] Hecht, J.E. (1999) Environmental Accounting-Where, We Are Now, Where We Are Heading. http://www.iucnus.org/greenacct.html

[7] Jane, G. and Joshi, L.P.D. (1999) A Survey of Environmental Accounting \& Reporting in Bahrain. Journal of Applied Accounting Research, 5, 4-36.

[8] Chauhan, M.D. (2005) Concept of Environmental Accounting and Practices in India. The Chartered Accountant.

[9] Gholami, S., et al. (2013) Environmental Accounting (From Concept to Practice). Journal of Basic and Applied Scientific Research, 3, 439-443.

[10] Ramesh, L. (2013) A Study of Environmental Accounting Practices in Selected Indian Companies. Kuvempu University, Karnataka.

[11] Dijk, V.A., et al. (2013) Environmental Reporting in Australia: Progress, Prospects and Research Priorities. Science of the Total Environment, 473-474, 338-349.

[12] Shil, N.C. and Iqbal, M. (2005) Environmental Disclosure-A Bangladesh Perspective. Paper No. 7707.

[13] Ali, M.M., Rashid, M.M. and Islam, M.A. (2010) Environmental Accounting and Its Applicability in Bangladesh. ASA University Review, 4, 23-37.

[14] Islam, S.M. and Das, C.P. (2013) Green Banking Practices in Bangladesh. Journal of Business Management, 8, 39-44.

[15] Ullah, H.M., Hossain, M.M. and Yakub, K.M. (2014) Environmental Disclosure Practices in Annual Report of the Listed Textile Industries in Bangladesh. Global Journal of Management and Business Research: Accounting and Auditing, 14, 97-108.

[16] Uddin, A.M. and Saifuddin, M. (2015) Narrative Reporting Disclosures: A Study of Selected Companies Listed in Dhaka Stock Exchange. The Cost and Management, 43, 41-50.

[17] Hossain, M.M. (2016) Environmental Reporting Practices in Annual Report of Selected Pharmaceuticals and Chemicals Companies in Bangladesh. International Journal of Business and Management Invention, 5, 20-28.

[18] Bouma, J.J. and Correlje, A. (2003) Institutional Changes and Environmental Management Accounting: Decentralisation and Liberalization. In: Environmental Management Accounting-Purpose and Progress, Springer, Berlin, 257-279.

[19] Burritt, R. and Saka, C. (2006) Environmental Management Accounting Applications and Eco-Efficiency: Case Studies from Japan. Journal of Cleaner Production Production, 14, 1262-1275. https://doi.org/10.1016/j.jclepro.2005.08.012 
[20] Setthasakko, W. (2010) Barriers to the Development of Environmental Management Accounting: An Exploratory Study of Pulp and Paper Companies in Thailand. EuroMed Journal of Business, 5, 315-331. https://doi.org/10.1108/14502191011080836

[21] Gale, R. (2006) Environmental Costs at a Canadian Paper Mill: A Case Study of Environmental Management Accounting (EMA). Journal of Cleaner Production, 14, 1237-1251.

[22] Deegan, C. (2003) Environmental Management Accounting: An Introduction and Case Studies for Australia. Institute of Chartered Accountants in Australia, Melbourne.

[23] International Federation of Accountants (IFAC) (2005) Environmental Management Accounting.

[24] UNDSD (2001) Environmental Management Accounting, Procedures and Principle. United Nations, New York. 


\section{Appendix 1}

\section{List of Samples Enterprise}

\begin{tabular}{cc}
\hline Industries & Enterprises \\
\hline Pharmaceuticals \& chemicals & Aristo pharma Ltd. \\
Textiles \& Clothing & GSK Ltd. \\
& Regency Garments Mills Ltd. \\
Papers \& Printing & KDS textile Ltd. \\
& Karnafuli Paper Mills Ltd. \\
Leather \& Footwear & Hakkani Pulp \& packaging Ltd. \\
& Apex Co. Limited \\
Steel Industry & Bata Shoe Company Limited \\
& KSRM \\
Foods Allied & RSRM \\
& BATBC \\
Energy & Kishowan Food Ltd. \\
& Jumona oil Ltd. \\
Cement & Rupsha Oil Ltd. \\
& Premier Cement \\
& Royal Cement Ltd. \\
& \\
&
\end{tabular}




\section{Appendix 2}

\section{Questionnaire}

\section{Confidential}

Title: Environmental Accounting Challenges of Selected Manufacturing Enterprises in Bangladesh

\section{Part-A: General Information}

1. Name and address of the enterprise:

2. Types of Industry:

3. Year of establishment:

4. Products: i. $\quad$ ii. $\quad$ iii.

5. No of employee/workers:

6. Name of the respondent:

7. Designation:

8. Last academic degree:

9. Age:

10. Do you have environmental clearance? Yes/ No

\section{Part-B: Specific information}

Key challenges in the environmental accounting in manufacturing organizations:

Here, High degree of positiveness 3, Moderately High 2, Somewhat High 1, No Reply 0, High degree of Negativeness-1, Moderately low -2 , Somewhat low -3 .

$$
\text { Statements for comments }
$$

$\begin{array}{lllllll}3 & 2 & 1 & 0 & -1 & -2 & -3\end{array}$

Cost involvement is an important issue to the enterprise in adopting environmental accounting.

Lack of skill manpower is an obstacle for environmental accounting.

Lack of consciousness in the manufacturing enterprises accounts for non-adoption of environmental accounting.

Lack of set rules about environmental accounting adversely affects proper implementation.

Absence of environmental accounting standard poses problem for standard compensation and presentation.

Lack of co-ordination with different stakeholders related with environmental issues affect proper implementation.

Inadequate economic policy or incentive system adversely affects motivation.

Institutional constraints adversely affect environmental accounting adoption.

Improper enforcement of planning and environmental legislation gives rise to low adoption

of environmental accounting.

Insufficient information about environmental issues affects recording \& presentation.

Inactive enterprise participation and slack governmental management accounts for low adoption of environmental accounting.

There are no specific principles of environmental accounting in Bangladesh.

Difficult to measure the environmental issues numerically which adversely affect proper environmental accounting practices. 